\title{
HISTORY OF CREATION SOVIET OF KARAKALPAK STATEHOOD
}

\author{
Djumashev A. \\ Candidate of historical sciences (PhD), senior researcher, Head of the Department History \\ Karakalpak research Institute of Humanities Karakalpak branch of the Academy of \\ Sciences, Republic of Uzbekistan, Nukus, Uzbekistan
}

\begin{abstract}
The purpose of the research is to reveal the features of the creation of the Soviet Karakalpak state. The article considers the processes of formation of the Karakalpak Autonomous region and its subsequent transformation from an independent region to an independent Republic. The conditions for administrative division in the Soviet state are shown. The article focuses on the fact that the entry of Karakalpakstan directly into Russia in the mid1930 s accelerated the process of transformation of Karakalpakstan from an independent region to an independent Republic. It is also noted that one of the reasons for joining Karakalpakstan to Russia and after its transformation into a political autonomy was the popular uprisings and rallies that took place in $1929-1930$ in Karakalpakstan, directed against the Soviet government. The scientific novelty of the work is that based on the identified new archival documents, it is determined that the level of economic, political and cultural development of Karakalpakstan allowed it to obtain political autonomy. As a result of this research, the stages that the Karakalpak people went through during the existence of the Soviet-type state are analyzed in detail.
\end{abstract}

KEYWORDS: the Soviet government, the state, the administrative-territorial division, national division, Karakalpakstan, an Autonomous region, the transformation.

\section{INTRODUCTION}

Formation of the Karakalpak independent area (further - KIA) and the transformation involved it from independent area in independent republic attracted attention of both historians, and lawyers, public figures, publicists. However some aspects of this process are unsufficiently covered by the researchers, engaging in the given problem. Till today the extensive scientific literature including the large monographies and generalizing works on given problem [2]. However is saved as show the new archival documents, revealed by us many aspects of this rather interesting problem remained outside of a field of sight of these authors, and they are rather valuable sources for disclosing the given question.

\section{DISCUSSION}

In Soviet state there were "rules" of administrative - territorial division or so-called Soviet autonomies, which existed in two forms: administrative and political. Number first included independent areas, together with the national districts, and in the second structure were only independent republics. Later the last could be transformed to allied republics. For successful passage of all these forms of administrative territorial division it was necessary strictly to observe these "rules".

Between administrative and political autonomies there were distinctions consisting in the following: the administrative autonomy was distributed only to sphere of management, and the political autonomy was embodied in the independent national state, which was characterized in more significant volume of the rights, presence of the own constitution, supreme bodies of state authority, legislation, government etc.

Today it is generelly accepted to consider, that created in 1922 at CC CPT(b) of the Khorezm republic the Kazakh-Karakalpak department, which literally in one year was transformed to independent area, was a first step on ways of restoration uniform Karakalpak national state of the Soviet type. 
April 5, 1924 CC CPT(b) at preliminary session has considered and has discussed the offer of the Central Asian Bureau CC CPT(b) (further - CAB) about national delimitation of Central Asia and in the decisions from June 12, September 25 and October 11,1924 has assigned on CAB a management of all party and Soviet work on delimitation and organization created republics [1].

In middle of June, 1924 in Tashkent the Responsible secretary CC CPT(b) I.M.Vareikis said on the radio, that expansion and the deepening of national state construction of Central Asia has revealed necessity of national delimitation. That is, formation in territory of Turkestan, Bukhara, Khorezm - Uzbek, Turkmen, Kirghiz (Kazakh) republics, two independent areas of the Kara-Kirghiz (Kirghiz) and Tadjiks.

For broadest populations of ideas of national delimitation, and also with the purposes of attraction of broad masses to discussion and development of the new state device, CAB CC CPT(b) offered to discuss at all party assemblies the general theses of national delimitation. Here it is necessary to pay attention that "broad masses" are there are those who participates on "party assemblies". Campaign of party discussion should begin immediately and finish by August 25 so that by September 1 were called plenums RC, on which the results of all these discussions should be moved.

After the message of Vareikis, A.Dosnszsrov (outstanding state figure of Karakalpakstan), which at will of destiny was in Tashkent and was at the centre of all occurring events, not waiting reaction from a management Amudaria of area, he himself actively participated in process of formation KIA. And at the end of September this question was already discussed in Moscow at session of a national commission on delimitation Turkestan.

Thus, October 27, 1924 on II sessions CEC USSR organized the Karakalpak independent area in structure Kazakh ASSR. In its structure Karakalpakstan was up to middle of 1930.

The way from reunification of Karakalpakstan and formation KIA in 1924 in structure of the Kazakh independent republic before reception of a political autonomy should be long even that Kazakhstan, as was told above, at this time was a political autonomy in structure of Russia. However entry of Karakalpakstan from middle of 1930 is direct in structure of Russia has sped up process of transformation of Karakalpakstan of independent area in independent republic. By one of occasions, which has served in business of connection of Karakalpakstan to Russia and after transformation it in a political autonomy, in our opinion those political processes which serve occured in 1929-1930 years in Karakalpakstan. That is national revolts and meetings directed against the Soviet authority. Thus, the independent area was transformed into independent republic, that is has received a political autonomy.

These facts are only description of the external party of development of this complicated process. As it is known, the history always is "made" by the people, and the political transformations, which were in Karakalpakstan, were not exception internal "engines" of all these processes there were concrete persons - unigrants from Karakalpakstan.

In March, 1932 at REC KIA the organizational commission "was formed on transformation of the Karakalpak independent area to independent republic" [3], which chairman was nominated by K.Nurmukhamedov. In the commission were: the assistant D.Loginov, secretary Doschanov, and also K.Avezov, D.Djanaliev, Chernikov and Sergeev.

At session of this commission, which held on that day, the agenda of forthcoming republican Constituent congress was considered. As we see, this commission developed organizational questions of transformation of Karakalpakstan, realization of congress, session etc. Also by decision of the given commission of March 5 that of year was called extraordinary IV plenum REC KIA, on which was decided to petition before Presidium CEC RSFSR for transformation of Karakalpakstan to independent republic (further KKASSR).

In turn Karakalpak RC $\mathrm{CP}(\mathrm{b})$ on a line of a party directs in CC CPT(b) the report with the request to support the decisions of the Karakalpak government.

The answer to the petition of the Karakalpak management was accepted by Presidium CEC RSFSR of the decision from March 29, 1932, where was spoken: "1. Karakalpaks independent area according to wich willy of its labor people to transform in existing borders in KKASSR.

2. By the supreme body of authority in territory KKASSR, down to convocation of its republican congress of councils to consider Karakalpak REC, which to charge with convocation of the first Karakalpak republican congress of councils for election CEC and organization of the device of authority" [4].

By the same decision it was entrusted to a department of Nationalities at Presidium CEC RSFSR to prepare "the Project of a rule about the state device KKASSR".

May 11, 1932 in Moscow behind the signatures of the chairman CEC RSFSR M.Kalinin and vice-president SPC RSFSR T.R.Rskulov was accepted The decision "About the statement of a rule about the state device KKACCP" [5].

In connection with transformation of Karakalpakstan to independent republic Karakalpak RS CP(b) and REC KIA have let out the reference to the worker of Karakalpakstan, in which the huge 


\section{EPRA International Journal of Research and Development (IJRD)

historical meaning of formation KKASSR for the further development of economy and culture of republic, for blossoming national state of the Karakalpak people was emphasized. According to it REC KIA has accepted the decision from March 28, 1932, on the basis of which the preparation for Constituent congress of councils KKASSR was widely developed.

May 25, 1932 in Turtkul (in that time was capital of Karakalpakstan) in solemn conditions has opened I Constituent congresses of councils KKASSR. May 29 the congress has finished the work and finally has ratified transformation of Karakalpakstan to independent republic.

Thus, on the basis of the revealed new archival documents, it is possible to reach a conclusion that the level of economic, political and cultural development of our territory has enabled to receive a political autonomy. It is necessary also to remember those who stood at sources of reception of this autonomy, outstanding state figures of Karakalpakstan. The influence them on all these processes connected to transformations, is very great. But, unfortunately, the reprisals of the 30-th years have destroyed many from them.

\section{CONCLUSION}

So, Karakalpak state of the Soviet type, which was created for the first time in 1922, in 1924 join uniform administrative independent in structure of Kazakhstan. With 1930 on 1936 гг. Karakalpakstan was in structure of Russia and in 1932 was transformed into a political autonomy. And from the end 1936 till the present time Karakalpakstan is in structure of Uzbekistan, and in December, 1990 it gets the sovereignty in structure of Uzbekistan. For all period of existence of the Soviet state type the set of historical events was Karakalpak which require separate research works. We here wanted to result only those materials, which show, what stages the Karakalpak people has passed during existence of the Soviet type state.

\section{REFERENCES}

1. Nazarov S. From the history of the Sredazburo of the Central Committee of the $R C P(b)$. (19221924) Tashkent, 1965., Allaniyazov B. Revolution mobilized. Nukus, 1991.

2. Rosenstein L. K. On the issue of education of the KKASSR. Nukus, 1957., Tatybaev S. To the history of converting KCAL to ASSR. Nukus, 1959., Kamalov S., Kalniyazov U. The great October revolution and the creation of the Karakalpak state. Nukus, 1987., Kulumbetov T. Development of Soviet statehood of the Karakalpak people. Nukus, 1966., Ahundzhanov D. The Establishment and development of socialist statehood in the Soviet Karakalpakstan. Nukus, 1984., etc.
3. Central state archive of the Republic of Karakalpakstan - Fund 229, list 1, case 67, page 15.

4. Central state archive of the Republic of Karakalpakstan - Fund 229, list 1, case 67, page 27.

5. Central state archive of the Republic of Karakalpakstan - Fund 229, list 1, case 67, page 1-2. 